\title{
Drive-by Photoscreening [Response to Letter]
}

This article was published in the following Dove Press journal:

Clinical Ophthalmology

\author{
Robert Arnold (iD) \\ Mason Keffalos ${ }^{2}$ \\ Samuel Martin' \\ 'Alaska Blind Child Discovery, \\ Anchorage, AK, USA; ${ }^{2}$ Boise State \\ University, Boise, ID, USA
}

Correspondence: Robert Arnold Alaska Blind Child Discovery, Alaska Children's EYE \& Strabismus, 3500, Latouche \#280, Anchorage, AK, 99508, USA

Tel + I 90756 I-1917

Fax + I 907563-5373

Email eyedoc@alaska.net

\section{Dear editor}

Thank you for the opportunity to respond to the excellent and informative letter by Dr. David Hunter.

For our attempt at Drive by Photoscreening, ${ }^{1}$ the wire-and-opaque-plastic shielded sufficient ambient light so that blinq could get a reading outdoors, but the performance of blinq suffered compared to conventional indoor use. We surmised this may have been due to the lack of facial view for the aiming beams, but we agree with Dr. Hunter that disruption of infrared light could also have been the culprit.

There remain some potential advantages to a hood, or tent between the patient and the screening device. ${ }^{2}$ These can decrease luminance and stray light. But they also can help fixation. Young and developmentally delayed children often do not understand the need to look at a small fixation target on an instrument-based screener so they may glance at peripheral distractions including the screener's face. If the screener then tries to "hide" behind the screening device, certain devices show the patient's face in their monitor so focus and alignment can be accomplished. Such device aiming is inherently obvious with smart phone photoscreening by GoCheck Kids. Viewing the patient's image on a monitor was not possible with the former MTI photoscreener or the current iScreen photoscreener which also made use of aiming beams like the blinq. In the future, it might be possible to include a small camera that projects the patient's face to the blinq monitor under these circumstances.

We remain amazed at the technology of the blinq and its potential to shed light on amblyopia, strabismus and perhaps many other entities. We hope the COVID-19 pandemic social distancing guidelines will soon be relaxed to allow even more widespread, valid early amblyopia detection worldwide.

\section{Disclosure}

Dr. Arnold is a board member of Glacier Medical Software that markets ROPCheck could-based NICU software. Dr. Arnold is a board member of PDI Check that makes a vision screening game for autostereoscopic screens on Nintendo 3DS. Dr. Arnold is the coordinator of the Alaska Blind Child Discovery which has received discounted vision screen technology from several vendors. Dr. Arnold is an investigator and protocol developer for the NIH-supported Pediatric Eye Disease Investigator Group (PEDIG). Dr. Arnold is a non-paid advisor to GoCheck Kids, plusoptiX, Adaptica and iScreen. The authors report no other conflicts of interest in this communication. 


\section{References}

1. Keffalos MA, Martin SJ, Arnold RW. Drive-By Photoscreening: plusoptiX, 2WIN and blinq Amblyopia Detection during the COVID-19 pandemic. Clin Ophthalmol. 2021;15:775-782. doi:10.2147/OPTH.S300871
2. Arnold RW, Stark L, Leman R, Arnold KK, Armitage MD. Tent photoscreening and patched HOTV visual acuity by school nurses: validation of the ASD-ABCD protocol. (Anchorage School DistrictAlaska Blind Child Discovery program). Binocul Vis Strabismus $Q$. 2008;23(2):83-94.

Dove Medical Press encourages responsible, free and frank academic debate. The content of the Clinical Ophthalmology 'letters to the editor' section does not necessarily represent the views of Dove Medical Press, its officers, agents, employees, related entities or the Clinical Ophthalmology editors. While all reasonable steps have been taken to confirm the content of each letter, Dove Medical Press accepts no liability in respect of the content of any letter, nor is it responsible for the content and accuracy of any letter to the editor.

\section{Publish your work in this journal}

Clinical Ophthalmology is an international, peer-reviewed journal covering all subspecialties within ophthalmology. Key topics include: Optometry; Visual science; Pharmacology and drug therapy in eye diseases; Basic Sciences; Primary and Secondary eye care; Patient Safety and Quality of Care Improvements. This journal is indexed on PubMed

Submit your manuscript here: https://www.dovepress.com/clinical-ophthalmology-journal
Central and CAS, and is the official journal of The Society of Clinical Ophthalmology (SCO). The manuscript management system is completely online and includes a very quick and fair peer-review system, which is all easy to use. Visit http://www.dovepress.com/ testimonials.php to read real quotes from published authors. 